W.M. Splinter MD FRCP, B. Smallman MD, E.J. Rhine MD FRCP, L. Komocar RN

\title{
Postoperative sore throat in children and the laryngeal mask airway
}

Postoperative sore throat is a minor complaint after general anaesthesia of multifactorial aetiology. The purpose of this study was to compare the effect of the laryngeal mask airway (LMA) and endotracheal tube (ETT) on postoperative sore throat in children. We hypothesized that the incidence of sore throat would be less after the use of the LMA. This was a randomized, single-blind study of 112 patients of age 3 to 12 yr undergoing minor peripheral surgery. The groups were similar, except that airway maintenance was either with an LMA or ETT. After induction of anaesthesia with $\mathrm{O}_{2}, \mathrm{~N}_{2} \mathrm{O}$ and halothane, an LMA or ETT was inserted. Anaesthesia was maintained with $\mathrm{O}_{2}, \mathrm{~N}_{2} \mathrm{O}$ and halothane. At the end of surgery, the ETT was removed in the operating room before airway reflexes had returned. The LMA was removed after the patient's airway reflexes had returned in the recovery room. On the first postoperative day, the parents were contacted and asked whether or not their child had had a sore throat. If a sore throat had been present, the parents rated the discomfort as mild, moderate or severe. The groups were similar with respect to age, weight. sex and duration of procedure. The overall incidence of sore throat was $9 \%$. The difference between the groups (LMA 13\% vs ETT 5\%) was not statistically significant. All of the reported sore throats were rated as mild. In conclusion, postoperative sore throat after minor paediatric surgery is uncommon. If it does occur, $i t$ is mild and the incidence is unaffected by the choice of an LMA or ETT.

En postopératoire, après une anesthésie générale, le mal de gorge constitue un inconvénient mineur d'étiologie variée. L'objectif de cette étude est de comparer l'influence du masque laryngé $(M L)$ avec la canule trachéale (CT) sur lincidence du

\section{Key words}

ANAESTHESIA: paediatric;

COMPLICATIONS: sore throat;

EQUIPMENT: airway, laryngeal mask.

From the Department of Anaesthesia, Children's Hospital of

Eastern Ontario and University of Ottawa, Ottawa, Canada.

Presented in part at the International Anesthesia Research

Society Annual Meeting, Orlando, Florida, March 1994.

Accepted for publication 10th July, 1994. mal de gorge chez l'enfant. Notre hypothèse initiale était que l'incidence des maux de gorge serait moindre avec le ML. Cette étude de 112 patients, âgés de 3 à 12 ans, soumis à une intervention périphérique mineure est aléatoire et à l'insu. Les groupes sont identiques sauf que la perméabilité des voies aériennes est obtenue soit avec un $M L$ soit avec une $C T$. Après linduction avec $\mathrm{O}_{2}, \mathrm{~N}_{2} \mathrm{O}$ et halothane, on introduit le $\mathrm{ML}$ ou la CT. L'anesthésie est maintenue avec $\mathrm{O}_{2}, \mathrm{~N}_{2} \mathrm{O}$ et halothane. $A$ la fin de la chirurgie, la CT est retirée en salle d'opération avant le retour des réflexes des voies aériennes. La ML est retiré en salle de réveil de la même façon. Le lendemain, les parents sont contactés et on leur demande si l'enfant se plaint de mal de gorge. Si la réponse est positive, on demande aux parents de le coter en léger, modéré ou grave. Les groupes sont identiques quant à l'âge, au poids, au sexe et à la durée de lintervention. Lincidence totale du mal de gorge est de $9 \%$. La différence entre groupe (ML $13 \%$ vs CT 5\%) n'est pas significative. Tous les maux de gorge ont été décrits comme légers. Pour conclure, le mal de gorge postopératoire n'est pas fréquent après une intervention pédiatrique mineure. Sil survient, il est léger et son incidence n'est pas influencée par le choix du ML ou de la CT.

Sore throat is a common minor complaint after general anaesthesia affecting as many as $60 \%$ of patients.' The aetiology is multifactorial and includes the following: endotracheal tube size and cuff design, lack of airway humidity, trauma during airway insertion and suctioning, high anaesthetic gas flow rates, and surgical manipulation of the airway and adjacent tissue. ${ }^{2,3}$

Increasingly the endotracheal tube (ETT) is being replaced by the laryngeal mask airway (LMA). The LMA is an effective method of airway management. It is easy to insert and is reusable. Once it has been properly positioned, it provides an incomplete seal around the laryngeal inlet, thereby leading to decreased contamination of the environment with anaesthetic gases. Another potential advantage of the LMA is the low incidence of sore throat reported by adults after anaesthesia. ${ }^{5} \mathrm{~A}$ similar investigation of children has not been performed. We compared the effects of the LMA and ETT on post- 
operative sore throat in children, hypothesizing that the incidence of sore throat would be lower with LMA insertion.

\section{Methods}

This randomized, single-blind study of 112 patients was completed with parental consent and approval of the Hospital Ethics Committee. The patients were assigned using a random number table to one of two study groups. The two groups were similar, except that airway maintenance of one group was with an LMA, while the other patients had an uncuffed ETT inserted. Patients were aged 3 to $12 \mathrm{yr}$ and had undergone peripheral general or plastic surgery. Patients -with preoperative sore throat, history of gastroesophageal reflux or those whose care would uniquely require an ETT or LMA were excluded from the study. At the time that the consent was obtained the parents were informed that they would be contacted the day after surgery to ascertain the severity of the child's sore throat. The uncomplicated four-point discomfort scale used in investigations of adults 1,4 was explained to parents. With this scale, discomfort is rated as 0 if none is present, 1 if it is mild, 2 if it is moderate and 3 if it is severe.

After the application of standard monitors and inhalational induction of anaesthesia with $\mathrm{O}_{2}, \mathrm{~N}_{2} \mathrm{O}$ and halothane, either an LMA or ETT was inserted by a staff anaesthetist or experienced residents (PGY3 or greater). The size and method of insertion of the airway followed published guidelines. ${ }^{5-7}$ The leak around the tracheal tube was between 5 and $30 \mathrm{~cm} \mathrm{H}_{2} \mathrm{O}$. Anaesthesia was maintained with $\mathrm{O}_{2}, \mathrm{~N}_{2} \mathrm{O}$ and halothane. There was no active humidification of the anaesthesia circuit. At the end of surgery, the ETT was removed in the operating room after gentle suctioning of the oropharynx and before airway reflexes had returned. The LMA was removed after the patient's airway reflexes had returned in the postanaesthetic recovery room by a recovery room nurse. Analgesia was provided by intraoperative regional anaesthesia. If necessary, analgesia was supplemented with postoperative acetaminophen and/or narcotics.

On the first postoperative day, the parents were contacted and questioned as to whether or not the child had had a sore throat. If a sore throat had been present, the parents were asked to rate the discomfort as mild, moderate or severe.

Sample size was predicted based upon a projected difference of $30 \%$ between the groups, a power of 0.80 , and the chance of a Type I error of 0.05 .

Demographic data were compared with Student's t test and Chi-square analysis, where appropriate. The incidence of sore throat was compared with Fisher's Exact Test. Accepted incidence of a Type I error was 5\%.
TABLE

\begin{tabular}{llllll}
\hline Group & $n$ & Age $(y r)$ & Weight $(\mathrm{kg})$ & $\begin{array}{l}\text { Incidence of } \\
\text { sore throat }\end{array}$ & $\begin{array}{l}\text { Anaesthesia } \\
\text { time (min) }\end{array}$ \\
\hline LMA & 55 & $6.9 \pm 2.5$ & $24 \pm 9$ & $13 \%$ & $44 \pm 16$ \\
ETT & 57 & $6.4 \pm 2.5$ & $23 \pm 9$ & $5 \%$ & $47 \pm 17$ \\
\hline
\end{tabular}

Mean \pm SD.

\section{Results}

The groups were similar with respect to age, weight, sex and length of operative procedure (Table). The overall incidence of sore throat was low, $9 \%$, and the difference between the groups was not statistically significant. All parents and children that reported postoperative sore throat in either group rated the discomfort as mild.

\section{Discussion}

The incidence of sore throat after minor peripheral surgery in children is low and appears not to be different whether an LMA or ETT is used. Our observed incidence and severity of sore throat after LMA insertion is similar to the $7-13 \%$ incidence of mild sore throat reported in adults. ${ }^{4,8-10}$

Of interest was the low incidence of sore throat observed after tracheal intubation in our population. Adult investigators have reported a $12-60 \%$ incidence of sore throat after tracheal intubation. ${ }^{1,2}$ Possible explanations for our low incidence may include the practice of avoiding topical gels and the brief surgical procedures undergone by our study patients. These factors may have minimized airway drying to insignificant levels. In addition our subjects had their airways instrumented by experienced clinicians. This may have resulted in decreased airway trauma during endotracheal intubation and suctioning of the oropharynx. Under-reporting by children and/or parents also may have contributed to our low reported incidence of sore throat. However, our observed incidence of sore throat after LMA was consistent with the findings of other investigators of children."

In conclusion, postoperative sore throat after minor paediatric surgery is uncommon. If it does occur, it is mild and the incidence is unaffected by the choice of an LMA or endotracheal tube.

\section{References}

1 Mandфe H, Nikolajsen L, Lintrup U, Jepsen D, Mølgaard $J$. Sore throat after endotracheal intubation. Anesth Analg 1992; 72: 897-900.

2 Loeser EA, Kaminsky A, Diaz A, Stanley TH, Pace NL. The influence of endotracheal tube cuff design and cuff lubrication on postoperative sore throat. Anesthesiology 1983; 58: 376-9. 
3 Cozine K, Stone JG. Determinants of postoperative sore throat. Anesthesiology 1993; 79: A24.

4 Alexander $C A$, Leach $A B$. Incidence of sore throats with the laryngeal mask (Letter). Anaesthesia 1989; 44: 791.

5 McEwan AI, Mason DG. The laryngeal mask airway. $\mathrm{J}$ Clin Anesth 1992; 4: 252-7.

6 Haynes $S R$, Morton NS. The laryngeal mask airway: a review of its use in paediatric anaesthesia. Paediatric Anaesthesia 1993; 3: 65-73.

7 McGinn G, Haynes SR, Morton NS. An evaluation of the laryngeal mask airway during routine paediatric anaesthesia. Paediatric Anaesthesia 1993; 3: 23-8.

8 Sarma VJ. The use of a laryngeal mask airway in spontaneously breathing patients. Acta Anaesthesiol Scand 1990; 34: 669-72.

9 Maltby $J R$, Loken $R G$, Watson NC. The laryngeal mask airway: clinical appraisal in 250 patients. Can J Anaesth 1990; 37: 509-13.

10 Janssens $M$, Maréchal $J$. The laryngeal mask - Liège experience. Acta Anaesthesiol Belg 1991; 42: 199-206.

11 Johnston DF, Wrigley $S R$, Robb PJ, Jones HE. The laryngeal mask airway in paediatric anaesthesia. Anaesthesia 1990; 45: 924-7. 